\title{
Comparison of yield, chemical composition and farinograph properties of common and ancient wheat grains
}

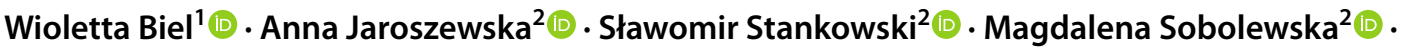 \\ Jagoda Kępińska-Pacelik ${ }^{1}$ (D)
}

Received: 11 January 2021 / Revised: 13 March 2021 / Accepted: 20 March 2021 / Published online: 29 March 2021

(c) The Author(s) 2021

\begin{abstract}
The chemical composition of 4 spring wheat species was analyzed: einkorn (Triticum monococcum) (local cv.), emmer (Triticum dicoccon) (Lamella cv.), spelt (Triticum spelta) (Wirtas cv.), and common wheat (Triticum aestivum) (Rospuda cv.). Mean emmer and einkorn yield was significantly lower than that of common wheat. The analyses of the wheat grain included the content of total protein, crude ash, crude fat, crude fibre, carbohydrates, phosphorus, potassium, magnesium, calcium, copper, iron, manganese, and zinc. The grains of the tested ancient wheats were richer in protein, lipids, crude fibre, and crude ash than the common wheat grains. The significantly highest levels of crude protein, ether extract, and crude ash were found in einkorn. As the protein concentration in the grain increased, the calcium, magnesium, and potassium levels increased, and the zinc and manganese levels decreased. Genotypic differences between the studied wheats were reflected in the concentrations of the minerals and nutrients, an observation which can be useful in further cross-linkage studies. Dough made from common wheat and spelt flour showed better performance quality classifying it to be used for bread production. In turn, flour from emmer and einkorn wheat may be intended for pastry products, due to short dough development time and constancy as well as high softening.
\end{abstract}

Keywords Chemical component $\cdot$ Farinograph properties $\cdot$ Triticum sp. Yield

Jagoda Kępińska-Pacelik

jagoda.kepinskapacelik@gmail.com

Wioletta Biel

wioletta.biel@zut.edu.pl

Anna Jaroszewska

anna.jaroszewska@zut.edu.pl

Sławomir Stankowski

slawomir.stankowski@zut.edu.pl

Magdalena Sobolewska

magdalena.sobolewska@zut.edu.pl

1 Division of Animal Nutrition and Food, Department of Monogastric Animal Sciences, West Pomeranian University of Technology in Szczecin, Klemensa Janickiego 29, 71-270 Szczecin, Poland

2 Department of Agroengineering, West Pomeranian University of Technology in Szczecin, Papieża Pawła VI 3, 71-459 Szczecin, Poland

\section{Introduction}

Over the entire history of humankind, the number of plant species consumed by humans has dropped from about 2000 to around 180. A growing awareness of the drastic drop in diversity in the human diet has renewed interest in ancient agricultural plant cultivars and species.

Wheat (Triticum L.) is a cereal which-due to its production potential and technological value-plays a unique role in the global economy. The most popular species is Triticum aestivum-common wheat [1], which forms the basis of human nutrition on all continents, and is an important source of nutrients in animal diets. It covers the largest sowing area in the agrarian structure of the world. In 2019, 763 million tonnes of wheat were produced globally [2]. Unfortunately, many valuable nutritional properties (microelements, vitamins, and organic compounds) and taste properties of wheat have been lost in the pursuit of performance and productivity. This has led to a recent renaissance in interest in the ancient species, which although being less productive have a higher 
nutritional value grain. In addition, these ancient species (e.g. emmer, einkorn, spelt) require much less chemical protection, resulting in lower environmental contamination [3].

Ancient grains can be used to make groats, flakes, and flour for baking organic bread. Emmer, as a result of crossing with a diploid species of chamois (Aegilops tauschii Coss.), led to the creation of spelt. As a result of further mutations occurring over several generations, spelt was made into common wheat [4]. Another increasingly popular cereal on organic farms is einkorn [5], which, due to its delicate structure (very thin stems and short ears) and relatively difficult cultivation, has survived in only a few regions [6]. In terms of structure and nutrient content, emmer and einkorn are more similar to spelt than common wheat [7]. They contain more easily absorbed protein, more fat-soluble vitamins (A, $\mathrm{D}, \mathrm{E}$ and $\mathrm{B}$ ) and microelements (phosphorus, iron, calcium, zinc, and manganese) [7-10]. Above all, they contain valuable amino acids (such as phenylalanine, tyrosine, and isoleucine), essential for the proper functioning of the nervous system. They also contain more easily assimilated forms of gluten [11-13]. Gliadins, which are not digested by people with coeliac disease, occur in forms with low toxicity. People who feel unwell after eating common wheat, generally have no digestive problems after eating ancient cereal products [14]. Finally, emmer, spelt and einkorn grains are protected by hulls (no longer existing in modern common wheat), a source of valuable micro and macro-elements [15].

The increase in yield in the modern wheat has been accompanied by a reduction in the levels of valuable nutrients in the grain, with adverse consequences for human nutrition [16-20]. This can be remedied by biofortification-cultivating wheat genotypes with high nutrient accumulation in the seeds. Another way is to find the genetic origins of health-promoting compounds in Triticum plants, to create newer more nutritious cultivars of the common wheat.

The chemical composition of flour determines the nutritional value of the products obtained from it. However, the technological suitability of flour to a large extent depends on its physicochemical characteristics. On the basis of the obtained pharynographic parameters, the quality and baking capacity of flour, and thus possible directions of its use, can be inferred.

The aim of this research was to verify the following hypotheses:

- grain of emmer, einkorn, spelt and common spring wheat cultivars are good sources mineral and nutritional components,

- flour of emmer, einkorn, spelt and common spring wheat cultivars characterize good parameters for baking cakes and bread.
Therefore, the aim of this study was to evaluate the yield, nutritional value, and farinograph properties of the whole grain and flour of spring accessions of emmer, einkorn, spelt, and common spring wheat cultivars with particular emphasis on the content and ratios of minerals.

\section{Materials and methods}

\section{Plant material and experimental design}

The research material consisted of 4 species of spring wheat: einkorn (a local variety without cultivar status), emmer (Lamella cv.), spelt (Wirtas cv.) and common wheat (Rospuda cv.). The grain was obtained from a field experiment conducted in 2018 at the Agricultural Experimental Station in Lipnik $\left(53^{\circ} 41^{\prime} \mathrm{N}, 14^{\circ} 97^{\prime} \mathrm{S}\right)$, which belongs to the West Pomeranian University of Technology in Szczecin, Poland. The experiment was performed on a typical rusty soil [21] classified as Haplic Cambisol with a slightly acidic reaction (pH $6.5 \mathrm{in} 1 \mathrm{~mol} \mathrm{KCl}$ ) according to the IUSS Working Group WRB [22], and with the following levels of assimilable forms of $\mathrm{P}_{2} \mathrm{O}_{5}-18.1, \mathrm{~K}_{2} \mathrm{O}-8.7, \mathrm{Mg}-2.6$, $\mathrm{S}^{-\mathrm{SO}_{4}}-1.62 \mathrm{mg} / 100 \mathrm{~g}$ soil. Oat was used as the pre-crop. After harvesting, the stubble was tended until winter plowing. In spring, the field was prepared using a cultivator with string rollers, and sowing was carried out at 350 grains $/ \mathrm{m}^{2}$ on April 15, 2018. Each plot area was 15 square meters, with six replications. The granulated fertilizers were used for fertilization. Fertilization with $17.44 \mathrm{~kg} \mathrm{P}, 52.80 \mathrm{~kg} \mathrm{~K}$ and $40 \mathrm{~kg} \mathrm{~N}$ per ha per hectare was applied before sowing the seed. Applied $\mathrm{P}$ as triple superphosphate, $\mathrm{K}$ as potassium salt, and $\mathrm{N}$ as ammonium saltpeter $34 \%$. A Wintersteiger field harvester was used after the grain had reached full maturity. The harvest was performed at the full maturity phase of the grain. The grain yield was measured in $\mathrm{kg}$ from plots and calculated in tones per hectare ( $\mathrm{t} / \mathrm{ha}$ ) adjusted to $12.5 \%$ of grain moisture.

\section{Weather conditions during vegetation cereals}

The average temperature during vegetation cereals was $17.1^{\circ} \mathrm{C}$, and sum of rainfall was $209.6 \mathrm{~mm}$. In relation to multi-year (1981-2010), the growing season of cereals in 2018 was drier and warmer. The average temperature and rainfall in multi-year were $13.5^{\circ} \mathrm{C}$ and $219 \mathrm{~mm}$, respectively. The humidity conditions in the period of the highest water demand of wheat, in the year of the study, were clearly unfavourable. With the exception of the month of July $(117.2 \mathrm{~mm})$, the sums of rainfall in individual months were nearly twice lower than the recommended optimal amount of rainfall $(\mathrm{mm})$ for this species. 


\section{Sampling preparation and chemical analysis}

The laboratory received a sample representative, not damaged, with not changed properties during transport and storage. The test sample was prepared in accordance with ISO 6498 [23]. The moisture of the obtained grain did not exceed $14-15 \%$, therefore it did not require additional drying [24]. Samples of harvested grains were ground to powder using a laboratory mill (KNIFETEC 1095, Foss Tecator, Sweden). The basic chemical composition (total protein, crude fat, crude fibre, total ash, and total carbohydrates) was determined according to the Association of Official Analytical Chemists [25].

The total content of potassium (K), calcium $(\mathrm{Ca})$, magnesium $(\mathrm{Mg})$, iron $(\mathrm{Fe})$, manganese $(\mathrm{Mn})$, zinc $(\mathrm{Zn})$, copper $(\mathrm{Cu})$ in the grains were determined by wet mineralization in a mixture of nitric $(\mathrm{V})$ and chloric (VII) acids at 1:1 ratio [26]. Analyses were performed using an Atomic Absorption Spectrometer (Thermo Fisher Scientific iCE 3000 Series, Waltham, Massachusetts, USA). For the determination of $\mathrm{Ca}, \mathrm{K}, \mathrm{Mg}$ the following has been set wavelengths: $\mathrm{K}$ : $766.5 \mathrm{~nm}$; Ca: $422.6 \mathrm{~nm}$; Mg: $285.2 \mathrm{~nm}$. For the determination of: Fe, Mn, Zn, Cu; Fe: $248.3 \mathrm{~nm}$; $\mathrm{Mn}$ : $279.5 \mathrm{~nm}$; Zn: $213.8 \mathrm{~nm} ; \mathrm{Cu}: 324.8 \mathrm{~nm}$. The calculation of the content of each element: $\mathrm{K}, \mathrm{Ca}, \mathrm{Mg}, \mathrm{Fe}, \mathrm{Mn}, \mathrm{Zn}$, and $\mathrm{Cu}$ was started with a calibration curve, taking into account the mass of the tested portion and the dilutions used. After mineralization of the grain in a solution of sulphuric (VI) acid and $\mathrm{H}_{2} \mathrm{O}_{2}$, phosphorus $(\mathrm{P})$ was determined by colorimetric method using ammonium molybdate at $470 \mathrm{~nm}$ [27]. Phosphorus contents were determined using a Specol 221 apparatus spectrophotometer (Carl Zeiss Jena, Germany). The absorbance value of the sample determined spectrophotometrically, from $\mathrm{P}_{2} \mathrm{O}_{5}$ to the total phosphorus content was calculated according to a chemical equivalent $(0.436)$. The reliability of the method used was confirmed by comparative studies, among others calibration curve, using the pattern series method.

According to the standard methods [28] were determined the rheological properties of the dough: flour water absorption (corrected to $14 \%$ ), development time ( $\mathrm{min}$ ), dough stability (min), and the degree of softening (FU), using a Brabender farinograph (Duisburg, Germany). Analyses were carried out for every combination in six replications.

\section{Statistical analyses}

The obtained results were statistically processed using a 1 -factorial variance of random blocks analysis. Confidence intervals were calculated using Tukey multiples tests assuming a significance level $p=0.05$. Results are presented as mean ( \pm standard deviation, SD) eight independent determinations. The correlation coefficients between the content of macro and microelements and protein in the grains of wheat were also calculated. Statistical analyses of the results were performed using Statistica 13.1 software.

\section{Results and discussion}

\section{Yield of four Triticum spp. species}

In terms of grain production, predominantly einkorn and emmer wheat produce a markedly lower yield than common wheat varieties. In own studies, the mean grain yield of four Triticum sp. species ranged from $4.8 \mathrm{t} / \mathrm{h}$ a for common wheat, $2.0 \mathrm{t} / \mathrm{h}$ a for einkorn wheat, $2.5 \mathrm{t} / \mathrm{ha}$ for emmer wheat and 3.2 t/ha for spelt (Fig. 1). Mean emmer and einkorn yield was significantly lower than that of common wheat, by $48 \%$ and $58.4 \%$, respectively [29]. Lacko-Bartosova and Ostepka [30] also observed lower yields of spelled as compared to common wheat. Rachoń et al. [31] obtained lower yields of both spelled and emmer than common wheat. However, in spite of their lower yields, the hulled wheat yields were stable under variable agro-meteorological conditions in subsequent years. The highest yield according to the cited authors [31], regardless of species, was noted in the year with higher precipitation total, with uniform distribution, and the lowest was noted in the year with the lowest precipitation total over the vegetation period. Probably the low yields of ancient wheats obtained in the own research resulted from the unfavourable humidity conditions prevailing during the growing season.

\section{Proximate composition}

In our experiment, the dry matter of the grain ranged from 90.4 to $90.9 \%$ (average $90.6 \%$ ) (Table 1 ).

Protein content is regarded as the most important characters influencing breadmaking. The protein content in grain is a hereditary feature, strongly modified by habitat-related and agrotechnical factors [32]. Proteins are

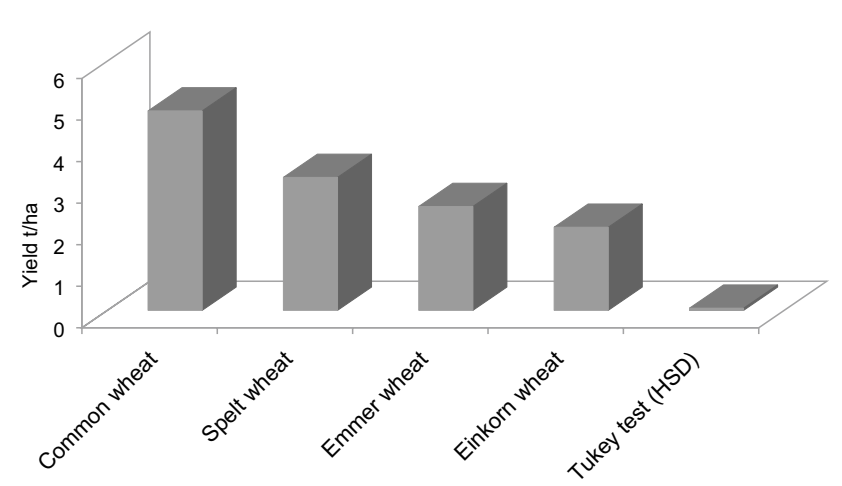

Fig. 1 Mean yield of grains of four Triticum sp. species 
Table 1 Basic chemical composition (g/100 g) in the grain of Triticum sp. species

\begin{tabular}{lllllll}
\hline Item & Dry matter & Crude protein $(N \times 5.7)$ & Ether extract & Crude ash & Crude fibre & TC \\
\hline Common wheat (Triticum aestivum) & $90.5 \pm 0.85^{\mathrm{a}}$ & $11.0 \pm 0.26^{\mathrm{d}}$ & $1.72 \pm 0.03^{\mathrm{c}}$ & $1.52 \pm 0.06^{\mathrm{d}}$ & $1.78 \pm 0.08^{\mathrm{b}}$ & $74.5 \pm 2.99^{\mathrm{a}}$ \\
Spelt wheat (Triticum spelta) & $90.7 \pm 0.85^{\mathrm{a}}$ & $12.8 \pm 0.31^{\mathrm{c}}$ & $2.17 \pm 0.03^{\mathrm{b}}$ & $1.86 \pm 0.07^{\mathrm{c}}$ & $1.96 \pm 0.08^{\mathrm{b}}$ & $71.9 \pm 2.90^{\mathrm{a}}$ \\
Emmer wheat (Triticum dicoccon) & $90.9 \pm 0.85^{\mathrm{a}}$ & $15.4 \pm 0.39^{\mathrm{b}}$ & $2.28 \pm 0.03^{\mathrm{ab}}$ & $2.16 \pm 0.07^{\mathrm{b}}$ & $5.03 \pm 0.10^{\mathrm{a}}$ & $65.9 \pm 2.46^{\mathrm{b}}$ \\
Einkorn wheat (Triticum monococcum) & $90.4 \pm 0.85^{\mathrm{a}}$ & $18.1 \pm 0.41^{\mathrm{a}}$ & $2.43 \pm 0.03^{\mathrm{a}}$ & $2.65 \pm 0.08^{\mathrm{a}}$ & $5.19 \pm 0.11^{\mathrm{a}}$ & $62.3 \pm 2.39^{\mathrm{b}}$ \\
Tukey test (HSD) & $\mathrm{ns}$ & 0.503 & 0.210 & 0.154 & 0.314 \\
SE & 1.323 & 0.128 & 0.0528 & 0.0387 & 0.0789 & 1.289 \\
CV \% & 3.37 & 2.18 & 5.99 & 3.95 & 5.55 \\
\hline
\end{tabular}

Mean values with the same letter ${ }^{(\mathrm{a}, \mathrm{b}, \mathrm{c}, \mathrm{d})}$ in each column are not significantly different at $p \leq 0.05$

$T C$ total carbohydrates, $S E$ standard error, $C V$ coefficient of variation, \pm standard deviation

responsible for many processes in the body, serving as a source of energy and essential amino acids. According to many authors, protein is the basic criterion for assessing the baking value of wheat, as it plays a crucial role in the process of creating the wheat dough. In our study, the highest protein content was determined in einkorn wheat $-18.1 \%$, followed by emmer (15.4\%), spelt $(12.8 \%)$ and common wheat (11.0\%). This confirms the results of other authors, showing that the ancient wheats are richer in protein than common wheat [33].

Lipids are minor wheat grain constituents, concentrated more in the germ (which contains $28.5 \%$ of lipids) and aleurone layer (8\%) than in the endosperm (1.5\%) [34]. It is also known that lipid content and composition depend on genetic variation, environmental effects during growth (including location, year, weather and soils) and the effects of the genetic $x$ environment interaction [35]. In our study, the significantly highest level of lipids was found in einkorn wheat $(2.43 \%)$, and the lowest level in common wheat (1.78\%). Similar to our study, Rachon et al. [36] found the lowest content of fat in the common wheat grain $(1.6 \%)$.

Cereal grain is a source of numerous mineral compounds, determined cumulatively as crude ash. The mineral compounds are important for nutritional and technological reasons. The ash content of the whole meal flour is generally high. In the study, the highest crude ash content was determined in einkorn wheat $-2.65 \%$, followed by emmer (2.16\%), spelt (1.86\%) and common wheat (1.52\%) [37].

Crude fibre is a component of dietary fibre, comprising cellulose, lignin, some hemicelluloses. In our study, crude fibre content in the wheat species varied greatly, ranging from 1.78 to $5.19 \%$. It was significantly highest in einkorn and emmer, and lowest in common wheat.

The main component of dry matter in the examined grains was total carbohydrate, which consisted of monosaccharides, starch, dextrins, and organic acids. In our study, the concentration of total carbohydrates was significantly highest in common wheat and spelt, and the lowest in emmer and einkorn.

\section{Mineral components}

Cereal grains are a rich source of valuable minerals, for both nutritional and technological reasons. Einkorn and emmer grains contained much more crude ash and total protein than common wheat, which indicates a higher capacity of ancient wheats to accumulate minerals. It also shows that the mineral composition of einkorn and emmer may be characterized by greater diversity or an increased concentration of minerals compared to bread wheats $[8,36]$.

The content of macroelements and microelements in the grain is primarily determined by genetics. The effect is so strong that wheat cultivars are divided into several classes (depending on the quality of the grain, from elite-E, with a very good baking value, to fodder $-\mathrm{C}$, (not useable for baking, e.g. for animals) [38]. Apart from the influence of the genotype, grain quality traits also depend on environmental conditions (especially climatic conditions) and the applied agricultural techniques [39-41]. The results of our study showed a significant variation in the content of macroelements in the grains of the tested wheat species (Table 2). Coefficients of variation (CV) for calcium, phosphorus, magnesium, and potassium were $9.7 \%, 5.56 \%, 3.65 \%$, and $3 \%$, respectively, which indicate greater differentiation of calcium levels compared to other macroelements in the grain, confirming the results obtained by Krochmal-Marczak and Sawicka [42]. Among the analyzed macroelements, potassium had the greatest concentration, followed by phosphorus and magnesium, then calcium. This descending order $(\mathrm{K}>\mathrm{P}>\mathrm{Mg}>\mathrm{Ca})$ was found in each of the wheat species analyzed.

Literature data $[18,43,44]$ indicate the superiority of ancient wheat species in terms of mineral content, which is partially confirmed by our study. With the exception of phosphorus, all the studied ancient wheats had a significantly 
Table 2 Macroelements $(\mathrm{g} / \mathrm{kg})$ content in grains of Triticum sp. species

\begin{tabular}{lllll}
\hline Item & $\mathrm{Ca}$ & $\mathrm{P}$ & $\mathrm{Mg}$ & $\mathrm{K}$ \\
\hline Common wheat (Triticum aestivum) & $0.11 \pm 0.02^{\mathrm{b}}$ & $5.16 \pm 0.13^{\mathrm{a}}$ & $1.04 \pm 0.07^{\mathrm{c}}$ & $4.74 \pm 0.10^{\mathrm{d}}$ \\
Spelt wheat (Triticum spelta) & $0.10 \pm 0.02^{\mathrm{b}}$ & $3.71 \pm 0.10^{\mathrm{c}}$ & $1.25 \pm 0.07^{\mathrm{b}}$ & $5.49 \pm 0.11^{\mathrm{c}}$ \\
Emmer wheat (Triticum dicoccon) & $0.15 \pm 0.02^{\mathrm{a}}$ & $4.73 \pm 0.12^{\mathrm{b}}$ & $1.34 \pm 0.07^{\mathrm{b}}$ & $5.84 \pm 0.11^{\mathrm{b}}$ \\
Einkorn wheat (Triticum monococcum) & $0.17 \pm 0.02^{\mathrm{a}}$ & $4.74 \pm 0.12^{\mathrm{b}}$ & $1.74 \pm 0.08^{\mathrm{a}}$ & $6.45 \pm 0.12^{\mathrm{a}}$ \\
Tukey test (HSD) & 0.024 & 0.414 & 0.0831 & 0.248 \\
SE & 0.006 & 0.105 & 0.0209 & 0.0689 \\
CV \% & 9.70 & 5.56 & 3.65 & 3.00 \\
\hline
\end{tabular}

Mean values with the same letter ${ }^{(\mathrm{a}, \mathrm{b} . \mathrm{c}, \mathrm{d})}$ in each column are not significantly different at $p \leq 0.05$

$S E$ standard error, $C V$ coefficient of variation, \pm standard deviation higher concentration of macroelements than common wheat, similar to that observed by Suchowilska et al. [9]. The study by Fan et al. [17] showed that newer wheat cultivars had lower levels of minerals in the grain, which is likely the result of mineral dilution due to the increased yields. In our study, the spelt grain contained the significantly least calcium, and was statistically not different from common wheat, which confirms the results of Suchowilska et al. [9]. The calcium content in spelt was $32 \%$ lower than in emmer and $40 \%$ lower than in einkorn. The level of phosphorus was significantly higher in common wheat grain than in the ancient wheats, by $9 \%$ compared to emmer and einkorn, and by $39 \%$ compared to spelt. Einkorn proved to be the richest in potassium, magnesium, and calcium, which confirms the results of Rachoń et al. [36]. Hidalgo and Brandolini [45] also found more magnesium in einkorn than in common wheat. In our study, the lowest concentrations of magnesium and potassium were recorded in the common wheat grain, $40 \%$ and $27 \%$ lower than in einkorn.

In our study, the concentrations of micronutrients in the grains of the studied wheat species varied significantly (Table 3). The coefficient of variation for calcium was the highest of the elements analyzed, at $\mathrm{CV}=7.45 \%$. Taking into account the differences in the elemental content of the grain, the micronutrients could be arranged in the following descending order: $\mathrm{Fe}>\mathrm{Mn}>\mathrm{Zn}>\mathrm{Cu}$. Grains of modern cultivars of common wheat (Triticum aestivum L.) are characterized by an ever-decreasing content of microelements $[17,46]$. In our study, the levels of zinc in all of the wheat species studied were almost half of those reported by Suchowilska et al. [9] and Morgounov et al. [47]. Significantly higher zinc levels were found in common wheat (by $62 \%$ ) compared to ancient wheats, which are usually considered to be a better source of microelements than their modern counterparts [9, 45]. Genc and MacDonald [48] found emmer grain to have higher zinc concentrations than modern durum wheat and bread wheat, which may prove that the mineral composition can be strongly modified by the genotype and habitat. In our study, zinc levels were lowest in emmer and einkorn $(17.8 \mathrm{mg} / \mathrm{kg})$. The concentration of iron in all four examined wheat genotypes was on average $80 \%$ higher than in literature data [39]. Iron had the highest concentration among the studied microelements and copper the lowest, which may be significant information for the cultivation of new cultivars containing high levels of iron. The significantly highest concentration of iron was found in spelt wheat follow by emmer grains, $61 \%$ and $32 \%$ more than in einkorn, which had the lowest iron concentration. Higher iron concentrations in spelt and emmer than in einkorn were also detected by Zhao et al. [49]. The highest concentrations of copper were found in common wheat $(2.345 \mathrm{mg} / \mathrm{kg})$, i.e. $53 \%$ more than in the studied ancient species of wheat, and $40 \%$ less than in the study by Suchowilska et al. [9].
Table 3 Microelements $(\mathrm{mg} / \mathrm{kg})$ content in grains of Triticum sp. species

\begin{tabular}{lllll}
\hline Item & $\mathrm{Fe}$ & $\mathrm{Zn}$ & $\mathrm{Mn}$ & $\mathrm{Cu}$ \\
\hline Common wheat (Triticum aestivum) & $60.8 \pm 4.25^{\mathrm{c}}$ & $28.8 \pm 1.28^{\mathrm{a}}$ & $44.8 \pm 1.01^{\mathrm{c}}$ & $2.345 \pm 0.10^{\mathrm{a}}$ \\
Spelt wheat (Triticum spelta) & $94.7 \pm 5.91^{\mathrm{a}}$ & $21.9 \pm 1.19^{\mathrm{b}}$ & $62.2 \pm 1.39^{\mathrm{a}}$ & $0.706 \pm 0.08^{\mathrm{c}}$ \\
Emmer wheat (Triticum dicoccon) & $77.6 \pm 5.18^{\mathrm{b}}$ & $17.8 \pm 1.08^{\mathrm{c}}$ & $47.1 \pm 1.15^{\mathrm{b}}$ & $0.662 \pm 0.08^{\mathrm{c}}$ \\
Einkorn wheat (Triticum monococcum) & $58.8 \pm 3.86^{\mathrm{c}}$ & $17.8 \pm 1.08^{\mathrm{c}}$ & $32.9 \pm 0.92^{\mathrm{d}}$ & $1.401 \pm 0.09^{\mathrm{b}}$ \\
Tukey test (HSD) & 4.02 & 1.55 & 2.09 & 0.155 \\
SE & 1.10 & 0.389 & 0.525 & 0.0389 \\
CV \% & 3.11 & 4.42 & 2.66 & 7.45 \\
\hline
\end{tabular}

Mean values with the same letter ${ }^{(\mathrm{a}, \mathrm{b}, \mathrm{c}, \mathrm{d})}$ in each column are not significantly different at $p \leq 0.05$ $S E$ standard error, $C V$ coefficient of variation, \pm standard deviation 
Significantly highest values of manganese were recorded in spelt, and lowest in einkorn (a difference of 90\%), with common wheat and emmer with intermediate values. The spelt grain in our study had a higher manganese content than the grain tested by Hussain et al. [39], where it ranged from 17 to $41.2 \mathrm{mg} / \mathrm{kg}$, depending on the location.

Calcium and magnesium deficiencies are common in many developed and developing countries [50]. Among other things, this is caused by air pollution and acidification of the body as a result of excessive consumption of processed food, as well as a deficit of the elements in soils. The grains of the tested wheat species proved to be a rich source of macroelements. With the exception of calcium, the levels of phosphorus, magnesium and potassium were higher than the recommended daily allowance (RDA) for macronutrients (Fig. 2). The studied wheats contained from 10 to $17 \%$ of the RDA for calcium (Fig. 2). The average concentration of magnesium in einkorn grain, the richest in magnesium among the examined wheats, was $61 \%$ higher than the RDA (Fig. 2). The concentration of phosphorus and potassium in all of the grains studied was several times higher than the RDA (Fig. 2). The grains tested can, therefore, be considered an excellent source of magnesium, phosphorus, and potassium, elements essential for many processes in human metabolism.

In a balanced diet, it is not only important to supply appropriate quantities of nutrients, but also their ratios have to be considered (Table 4).

An inadequate calcium-magnesium ratio $(\mathrm{Ca}: \mathrm{Mg})$ has gained great attention in recent years as a factor increasing the risk of metabolic, inflammatory, and cardiovascular disorders. When the calcium concentration is high, magnesium absorption can be significantly reduced. It is recommended that the calcium-magnesium ratio be close to 2 [51]. In the studied wheat grains, the ratio was very low, close to 0.1 (Table 4), due to the high magnesium and low calcium concentrations. Similar results were obtained by Ostrowska and Porębska [52] and Wojtkowiak et al. [53], who argued that cereal grains, including wheat, contain lower concentrations of calcium than magnesium, and therefore the $\mathrm{Ca}: \mathrm{Mg}$ ratio in cereals is lower than 1 . The most common reason for low calcium concentrations in cereals is soil acidification, and the excessive use of nitrogen fertilizers without the addition of other elements. The low calcium content in the
Fig. 2 Content of macroelements in grain with respect to recommended daily allowance (RDA)
Table 4 Selected macro- and microelement ratios in grain of Triticum sp. species

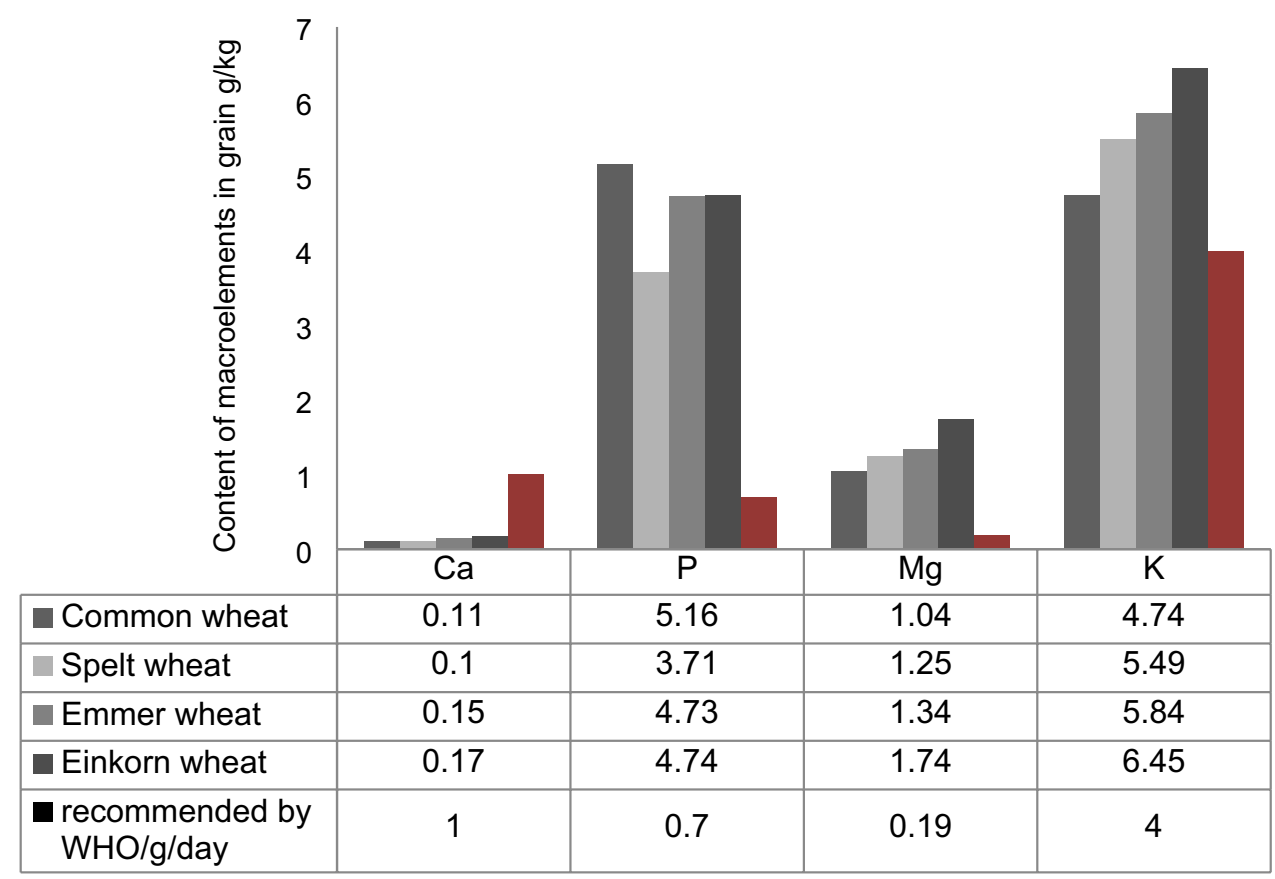

\begin{tabular}{llllll}
\hline Item & Ca: $: \mathrm{Mg}$ & $\mathrm{K}: \mathrm{Mg}$ & $\mathrm{Ca}: \mathrm{P}$ & $\mathrm{Fe}: \mathrm{Zn}$ & $\mathrm{Zn}: \mathrm{Cu}$ \\
\hline Common wheat (Triticum aestivum) & 0.11 & 4.56 & 0.02 & 2.11 & 12.3 \\
Spelt wheat (Triticum spelta) & 0.08 & 4.39 & 0.02 & 4.32 & 31.0 \\
Emmer wheat (Triticum dicoccon) & 0.11 & 4.36 & 0.03 & 4.36 & 26.9 \\
Einkorn wheat (Triticum monococcum) & 0.10 & 3.71 & 0.04 & 3.30 & 12.7 \\
\hline
\end{tabular}


human diet may, therefore, result from its low concentration in agricultural products, which are the primary sources in food [52].

Another important ratio in the mammalian diet, $\mathrm{K}: \mathrm{Mg}$, should not exceed six [54]. In the examined grains it was generally favorable, ranging from 3.71 in einkorn to 4.56 in common wheat (Table 4).

The main function of phosphorus is in forming bones and teeth. It also affects the body's use of carbohydrates and fats. An excessive phosphorus intake can lead to a reduction in bone mass, and when accompanied by a low calcium intake it can affect the hormones that regulate calcium metabolism and vitamin D synthesis [55]. According to the RDA, a correct ratio of $\mathrm{Ca}: \mathrm{P}$ in the human diet should be 1.5:1. With respect to the content of these macroelements in the examined grains, all the analyzed wheat species were characterized by a lower $\mathrm{Ca}: \mathrm{P}$ ratio than that recommended for the human diet (Table 4), which confirms the results obtained by Pontieri et al. [56]. Main reservoir of phosphorous $(\mathrm{P})$ in plants is phytic acid is a and contributes to about $80 \%$ of the total $\mathrm{P}$ in cereal seeds. Phytic acid have possess anti-nutritional behavior. Due to its molecular structure, phytic acid shows a high affinity to polyvalent cations, such as minerals and trace elements, and interferes in their intestinal absorption. Therefore, the interaction between phytic acid and minerals should be taken into consideration to ensure high bioavailability and an adequate supply of them. In previous research described the negative effect of phytates on the bioavailability of minerals and trace elements $[57,58]$. However, with well-balanced nutrition this seems to be a less significant problem. In industrialised countries where various civilisation diseases are prevalent, the beneficial properties of phytic acid, such as its anticancer, antioxidative, and anticalcification activities, are of great importance [58]. The biggest concern related to the lack of microelements in the human population are iron and zinc deficiencies, mainly due to their low concentration in cereals as well as the number of people affected worldwide [39, 59]. Zinc and iron deficiencies are some of the most significant factors in diseases in developing countries according to the World Health Organisation [60]. With the exception of copper, the concentrations of micronutrients in the grains we studied were higher than the RDA (Fig. 3). The wheat species we studied can, therefore, be excellent sources for developing new cultivars of wheat with high zinc and iron content.

In human nutrition, zinc and iron are often evaluated together because these minerals share a common dietary source [61], and their absorption is inhibited by similar compounds [62]. Importantly, excessive iron supply can cause zinc absorption disorders. Research has shown that a Fe: Zn ratio in the diet of 1:1 is accompanied by a slight inhibition of zinc absorption, while ratios of $2: 1$ or $3: 1$ significantly reduce absorption [63]. In our study, the ancient grain had a higher iron content than zinc, and hence the ratio of both elements in the grain was generally unfavorable (Table 4).

Copper deficiency is not common in humans, but it can cause several adverse health effects, such as reduced red blood cell count and frequent infections. Zinc and iron are copper antagonists and at high concentrations [64], zinc ions may reduce the absorption of copper ions. To avoid
Fig. 3 Content of microelements in grain with respect to recommended daily allowance (RDA)

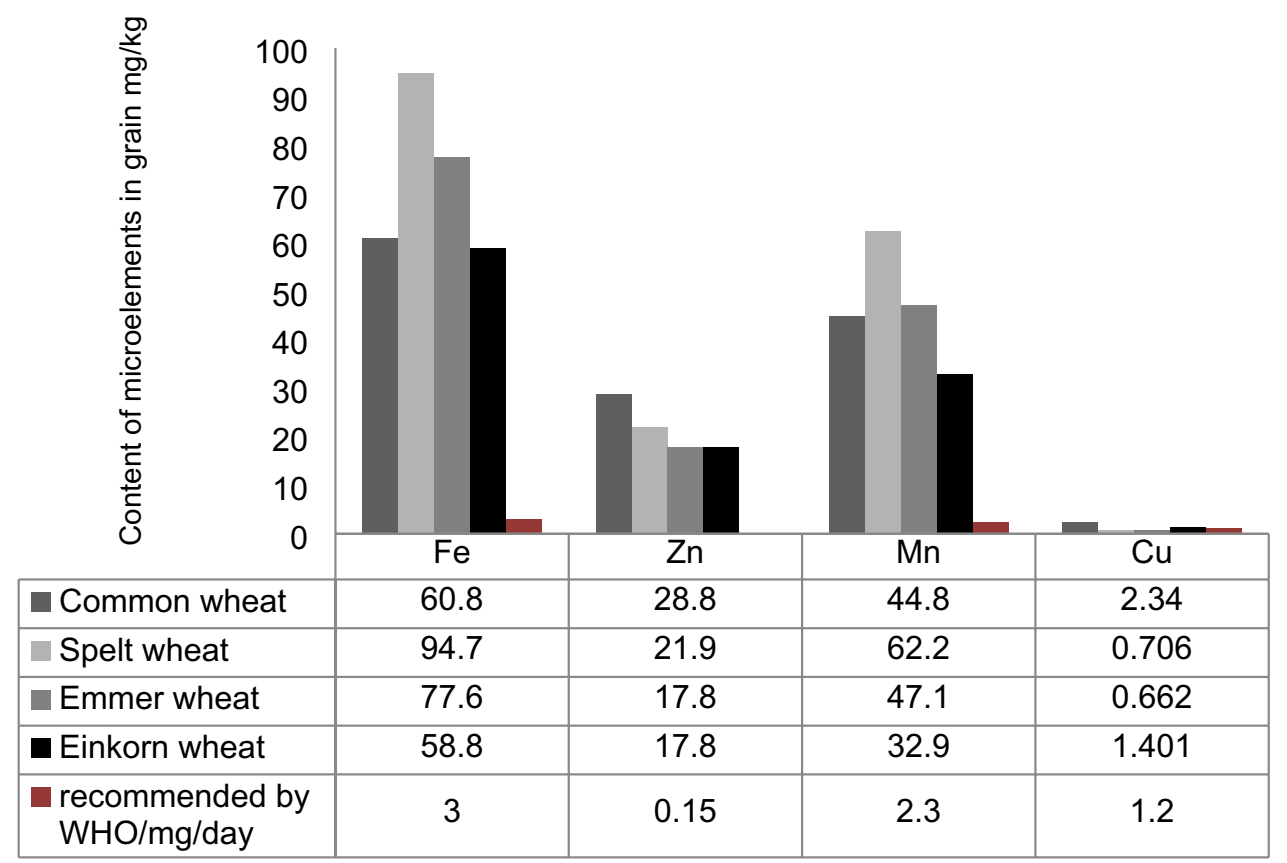


secondary copper deficiency, it is important to maintain the correct ratio between zinc and copper in the diet. The risk of copper deficiency is greatest when the $\mathrm{Zn}: \mathrm{Cu}$ ratio exceeds 18 [65]. As far as dietary recommendations are concerned, the most favorable $\mathrm{Zn}: \mathrm{Cu}$ ratio was that found in common wheat and einkorn grains (Table 4).
Correlations between the traits are of great importance for the selection of cultivars in breeding programs. Genotypes with increased levels of nutrients and minerals can be effective components of functional foods and improve the nutritional quality of the products [66]. Our study showed that the protein levels positively correlated with the levels of calcium
Fig. 4 Correlation coefficient between Ca content (y) and protein of wheat grain, $n=8$
Fig. 5 Correlation coefficient between $\mathrm{Mg}$ content (y) and protein of wheat grain, $n=8$
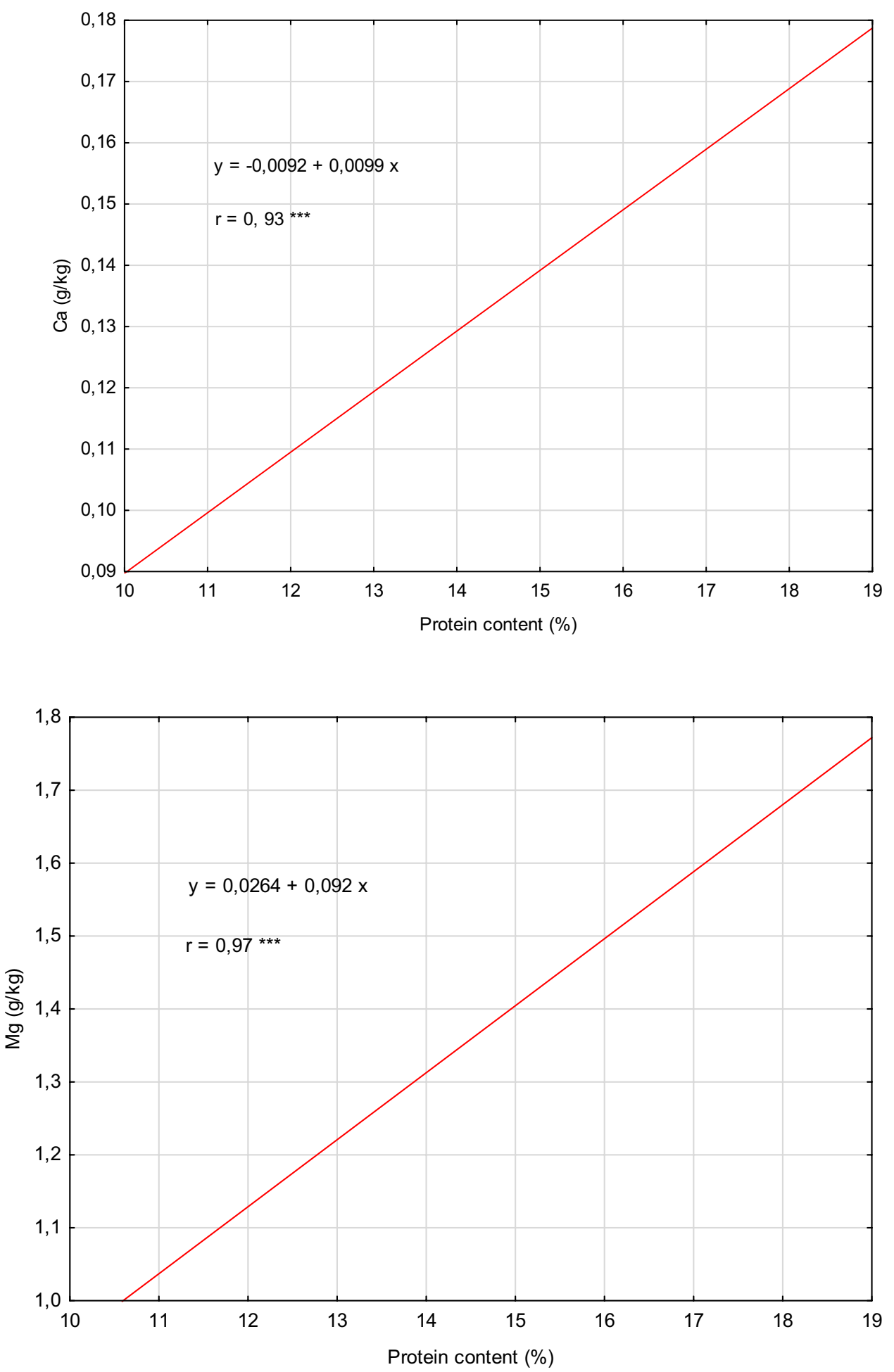
Fig. 6 Correlation coefficient between K content (y) and protein of wheat grain, $n=8$

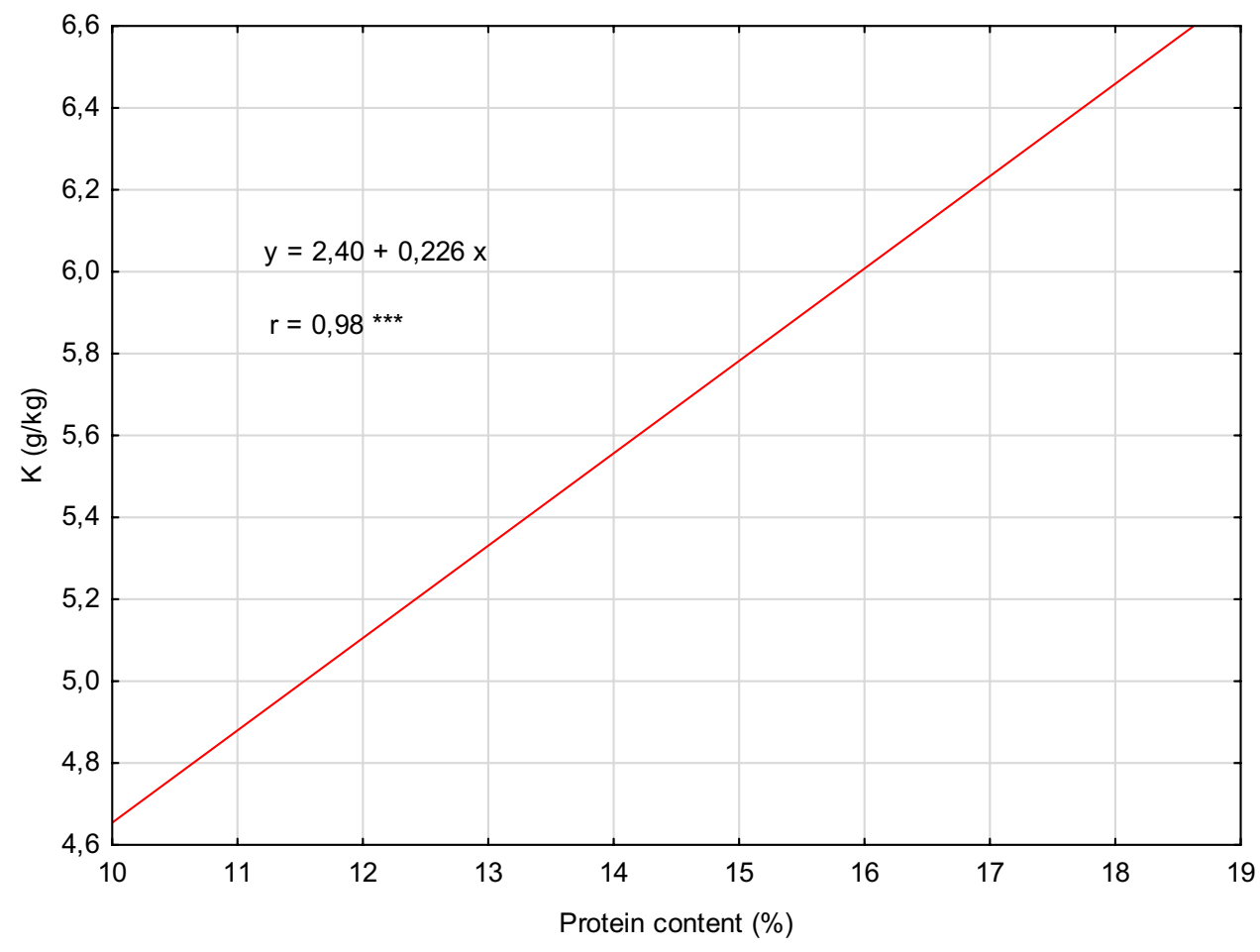

( $r=0.93)$, potassium $(r=0.98)$ and magnesium $(r=0.97)$, which suggests a possibility of creating new cultivars rich in protein and minerals from a single genotype (Figs. 4, 5, 6). With an increase in protein concentration by one unit, the calcium content increased by $0.0099 \mathrm{~g} / \mathrm{kg}$, potassium by $0.226 \mathrm{~g} / \mathrm{kg}$ and magnesium by $0.092 \mathrm{~g} / \mathrm{kg}$. The correlation between the concentrations of various mineral nutrients may indicate the existence of one or more common genetic and physiological mechanisms involved in the absorption or uptake of minerals by the root system, translocation and redistribution in plant tissues, remobilization to the grain, and accumulation in the developing grain [67]. According to our research and other reports, wheat species with a higher protein concentration in the grain also showed higher levels of calcium and magnesium [42, 67].

The basic functions of zinc include catalyzing enzyme activity, contributing to protein structure, and regulating gene expression [68]. Protein content was negatively correlated with zinc content $(r=-0.89)$ (Fig. 7). The reduction in protein concentration by one unit resulted in a decrease in zinc concentration by $1.49 \mathrm{mg} / \mathrm{kg}$. A significant positive correlation between grain protein concentration and zinc was found by Peleg et al. [69], which was supported by a significant overlap of relevant quantitative trait loci (QTL), and suggests common physiological and/or genetic factors controlling the concentration of these mineral nutrients. Other studies did not show a significant relationship between protein and zinc content in wheat grains [70], which, according to the quoted authors, may be related to the origin of the material, and require further research. Similarly, the reduction of protein content by one unit reduced the concentration of manganese in the tested grain by $2.40 \mathrm{mg} / \mathrm{kg}(r=-0.72)$ (Fig. 8). Chatzav et al. [67] noted a positive correlation between protein and manganese concentrations in cereal grains.

\section{Farinograph properties}

In the milling and baking industry, in order to achieve highquality products, the dough must have optimum rheology [71]. High water absorption, combined with a low degree of softening indicates good quality flour, whereas high water absorption combined with a high degree of softening indicates poor quality flour [72]. In general, the water content in bread dough is around $65 \%$. When the water content is lower than optimal, the mixing time will increase [73]. Water absorption values of flour under analysis ranged from 58.2 to $65.5 \%$ and showed significant differences depending on a given wheat form (Table 5). Out of the analysed flour, the highest water absorption was determined in emmer and einkorn flour, which can be attributed to a high concentration of protein in the grain of both wheat forms (Table 1). Water absorption is closely related to the amount of protein. Flour of high protein content absorbs more water [74]. Dough development time depends on the amount and quality of gluten of flour and its water-binding 
Fig. 7 Correlation coefficient between $\mathrm{Zn}$ content (y) and protein of wheat grain, $n=8$

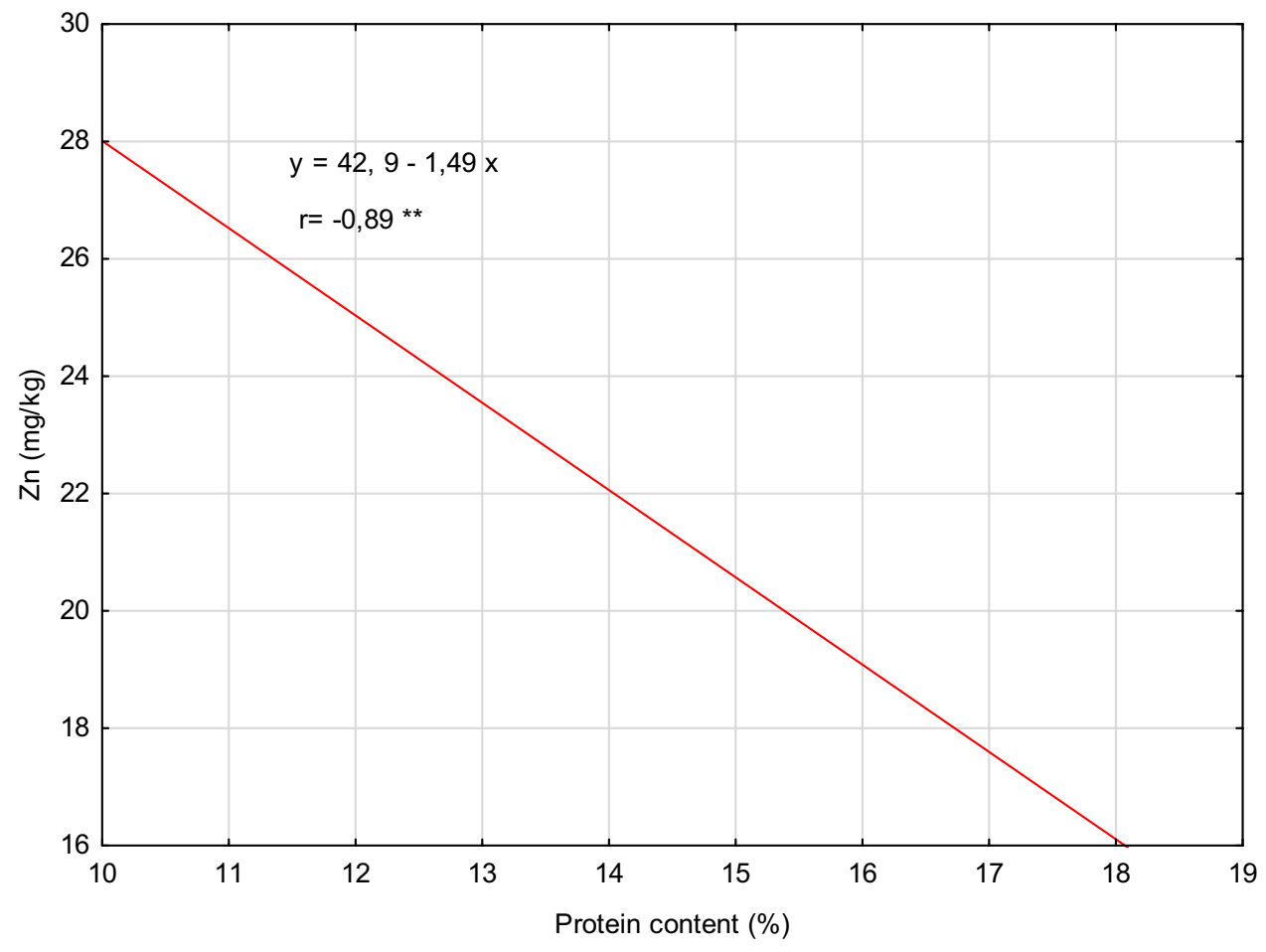

Scatterplot: Protein content (\%) vs. Mn (mg/kg)

$\mathrm{Mn}(\mathrm{mg} / \mathrm{kg})=81,078-2,396{ }^{*}$ Protein content $(\%)$

Correlation: $r=-, 6169$

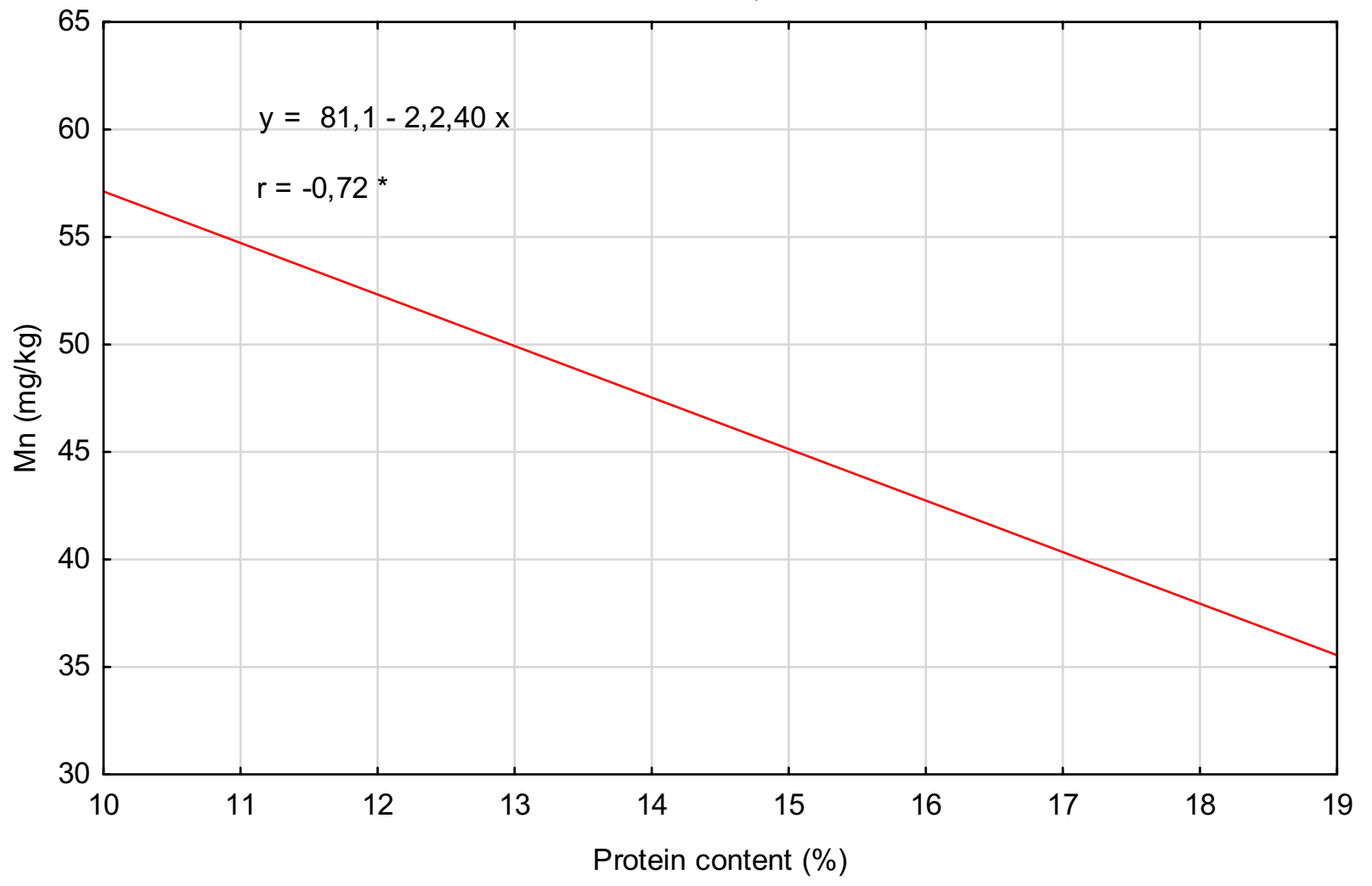

Fig. 8 Correlation coefficient between Mn content (y) and protein of wheat grain, $n=8$ 
Table 5 Farinograph properties of grain and flour of Triticum sp. species

\begin{tabular}{|c|c|c|c|c|c|}
\hline \multirow[t]{2}{*}{ Item } & \multirow[t]{2}{*}{ Water absorption (\%) } & \multirow{2}{*}{$\begin{array}{l}\text { Development } \\
\text { time (min) }\end{array}$} & \multirow[t]{2}{*}{ Stability (min) } & \multicolumn{2}{|c|}{ Degree of softening (FU) } \\
\hline & & & & after $10 \mathrm{~min}$ & after $12 \min$ \\
\hline Common wheat (Triticum aestivum) & $60.7 \pm 0.38^{c}$ & $4.8 \pm 0.10^{\mathrm{a}}$ & $4.40 \pm 0.31^{\mathrm{a}}$ & $69.7 \pm 1.21^{\mathrm{d}}$ & $93.0 \pm 2.68^{\mathrm{d}}$ \\
\hline Spelt wheat (Triticum spelta) & $58.2 \pm 0.44^{\mathrm{d}}$ & $3.9 \pm 0.16^{\mathrm{b}}$ & $4.15 \pm 0.29^{\mathrm{a}}$ & $78.0 \pm 1.09^{\mathrm{c}}$ & $99.3 \pm 2.68^{c}$ \\
\hline Emmer wheat (Triticum dicoccon) & $65.5 \pm 0.43^{\mathrm{a}}$ & $2.1 \pm 0.10^{c}$ & $1.43 \pm 0.28^{b}$ & $163.0 \pm 1.41^{\mathrm{b}}$ & $184.3 \pm 1.63^{b}$ \\
\hline Einkorn wheat (Triticum monococcum) & $61.3 \pm 0.24^{b}$ & $2.1 \pm 0.12^{\mathrm{c}}$ & $1.20 \pm 0.21^{\mathrm{b}}$ & $182.5 \pm 1.38^{\mathrm{a}}$ & $192.7 \pm 1.97^{\mathrm{a}}$ \\
\hline Tukey test (HSD) & 0.620 & 0.206 & 0.452 & 2.083 & 3.292 \\
\hline SE & 0.553 & 0.245 & 0.314 & 10.43 & 9.665 \\
\hline $\mathrm{CV} \%$ & 0.61 & 4.19 & 9.04 & 1.19 & 1.61 \\
\hline
\end{tabular}

Mean values with the same letter ${ }^{(\mathrm{a}, \mathrm{b}, \mathrm{c}, \mathrm{d})}$ in each column are not significantly different at $p \leq 0.05$

$S E$ standard error, $C V$ coefficient of variation, \pm standard deviation

capacity. Dough development time showed that common wheat and spelt flour required the most time to hydrate and obtain specified maximum dough consistency (Table 5). Lower respective values were recorded for dough made from emmer and einkorn wheat-on average $2.1 \mathrm{~min}$. In the study of Rao et al. [75] dough development time ranged from 2.60 to $7.00 \mathrm{~min}$ in the emmer-derived genotypes. According to Lacko-Bartošová et al. [76] in emmer wheat genotypes dough development time ranged from 0.49 to $1.41 \mathrm{~min}$. Apart from the aforementioned factors, growing habitat conditions also affect the pharyngographic parameters. High variability of rheological parameters of wheat quality depending on location and year of production was documented by Tomić et al. [77]. Stability is an indicator of flour tolerance to mixing. Higher values suggest a stronger dough. The higher the tolerance, the longer the dough should be mixed [78]. Flour of emmer and einkorn wheat exhibited the lowest stability (below 1.43), which indicates a shorter mixing time (Table 5). Higher values of the degree of softening indicate that dough will not be able to sustain long mechanical processing treatments (overmixing) [76]. Dough made from emmer and einkorn wheat showed a markedly higher degree of softening than dough made from common wheat and spelt flour (Table 5). High softening values of emmer wheat dough were also obtained by Lacko-Bartošová et al. [76]. In turn, Marconi et al. [79] confirm that spelt dough softening values exceed $50 \mathrm{FU}$, reaching as much as $140 \mathrm{FU}$.

According to the classification by Rohlich and Bruckener, strong flour is characterised by water-absorbing capacity of more than 59\%, dough development time longer than 3 min, dough constancy of more than $4 \mathrm{~min}$, and softening value of less than 40 . For weak flour the characteristics are as follows: water-absorbing capacity below $51 \%$, the development time of less than $2 \mathrm{~min}$, constancy less than $1 \mathrm{~min}$ and softening above $150 \mathrm{FU}$. The flour under analysis can be classified as intermediate flour.

\section{Conclusions}

The most favorable nutritional properties had a grain of ancient wheats. The grains of the tested ancient wheats were richer in protein, lipids, crude fibre, and crude ash than the common wheat grain. Of the studied wheats, einkorn was the richest in potassium, magnesium, and calcium. The common wheat grain had the highest content of phosphorus, zinc and copper, and spelt was the richest in iron and manganese. As the protein concentration in the grain increased, the calcium, magnesium and potassium levels increased, and zinc and manganese levels decreased. Einkorn and common wheat had a favorable K:Mg ratio. Genotypic differences between the studied wheats are reflected in the concentrations of minerals and nutrients, which can be useful in further cross-linkage studies. The assessment of genetic variability in terms of nutrient content is essential for the success of breeding activities aimed at developing new wheat genotypes which could be used as crops, or as a material for growing new nutrient-rich common wheat cultivars. Therefore, it is necessary to continue research on the chemical composition of various forms of wheat grown under different habitat conditions. Dough made from common wheat and spelt flour showed better performance-longer development time and dough constancy, lower degree of softening, classifying it to be used for bread production. In turn, flour from emmer and einkorn wheat may be intended for pastry products, due to short dough development time and constancy as well as high softening. The ancient wheats reacted with a reduction in yield to the unfavorable moisture conditions in the year of the study.

Author contributions $\mathrm{WB}, \mathrm{AJ}-$ conceived and designed the research. WB, AJ, SS, MS, JK-P—performed the experiments, analyzed data 
and wrote the manuscript. All the authors read and approved the manuscript.

Funding Not applicable.

Availability of data and materials Available upon request.

\section{Declarations}

Conflict of interest The authors declare no conflict of interest.

Compliance with ethics requirements This chapter does not contain any studies with animals performed by any of the authors.

Open Access This article is licensed under a Creative Commons Attribution 4.0 International License, which permits use, sharing, adaptation, distribution and reproduction in any medium or format, as long as you give appropriate credit to the original author(s) and the source, provide a link to the Creative Commons licence, and indicate if changes were made. The images or other third party material in this article are included in the article's Creative Commons licence, unless indicated otherwise in a credit line to the material. If material is not included in the article's Creative Commons licence and your intended use is not permitted by statutory regulation or exceeds the permitted use, you will need to obtain permission directly from the copyright holder. To view a copy of this licence, visit http://creativecommons.org/licenses/by/4.0/.

\section{References}

1. Figueroa M, Hammond-Kosack KE, Solomon PS (2018) A review of wheat diseases-a field perspective. Mol Plant Pathol. https:// doi.org/10.1111/mpp.12618

2. FAO (2020) Crop Prospects and Food Situation-Quarterly Global Report No. 4, December 2020. Food and Agriculture Organization, Rome. https://doi.org/10.4060/cb2334en

3. Bencze S, Makádi M, Aranyos TJ, Földi M, Hertelendy P, Mikó P, Bosi S, Negri L, Drexler D (2020) Re-introduction of ancient wheat cultivars into organic agriculture-emmer and einkorn cultivation experiences under marginal conditions. Sustainability. https://doi.org/10.3390/su12041584

4. Zacharieva M, Ayana NG, Hakimi AA, Misra SC, Monneveux P (2010) Cultivated emmer wheat (Triticum dicoccon Schrank), an old crop with promising future: a review. Genet Resour Crop Evol. https://doi.org/10.1007/s10722-010-9572-6

5. Zorovski P, Popov V, Georgieva T (2018) Growth and development of Triticum monococcum L., Triticum dicoccum Sch. and Triticum spelta $\mathrm{L}$. in organic farming conditions. Contemp Agric $1: 45-50$

6. Hajnalová M, Dreslerová D (2010) Ethnobotany of einkorn and emmer in Romania and Slovakia: towards interpretation of archaeological evidence. Památ Archeol 101:169-202

7. Suchowilska E, Wiwart M, Borejszo Z, Packa D, Kandler W, Krska R (2009) Discriminant analysis of selected yield components and fatty acid composition of chosen Triticum monococcum, Triticum dicoccum and Triticum spelta accessions. J Cereal Sci 2:310-315

8. Hidalgo A, Brandolini A, Ratti S (2009) Influence of genetic and environmental factors on selected nutritional traits of Triticum monococcum. J Agric Food Chem. https://doi.org/10.1021/jf901 $180 \mathrm{q}$

9. Suchowilska E, Wiwart M, Kandler W, Krska R (2012) A comparison of macro- and microelement concentrations in the whole grain of four Triticum species. Plant Soil Environ. https://doi.org/ 10.17221/688/2011-PSE

10. Ziegler JU, Wahl S, Würschum T, Longin CFH, Carle R, Schweiggert RM (2015) Lutein and lutein esters in whole grain flours made from 75 genotypes of 5 Triticum species grown at multiple sites. J Agric Food Chem. https://doi.org/10.1021/acs.jafc.5b014 77

11. Vincentini O, Maialetti F, Gazza L, Silano M, Dessi M, De Vincenzi M, Pogna NE (2007) Environmental factors of celiac disease: cytotoxicity of hulled wheat species Triticum monococcum, T. turgidum ssp. dicoccum and T. aestivum ssp. spelta. J Gastroenterol Hepatol. https://doi.org/10.1111/j.1440-1746.2006.04680.x

12. Vincentini O, Borrelli O, Silano M, Gazza L, Pognac N, Luchetti R, De Vincenzi M (2009) T-cell response to different cultivars of farro wheat, Triticum turgidum ssp. dicoccum, in celiac disease patients. Clin Nutr 3:272-277

13. Giacintucci V, Guardeño L, Puig A, Hernando I, Sacchetti G, Pittia $\mathrm{P}$ (2014) Composition, protein contents, and microstructural characterisation of grains and flours of emmer wheats (Triticum turgidum ssp. dicoccum) of the central Italy type. Czech J Food Sci. https://doi.org/10.17221/512/2012-CJSF

14. Escarnot E, Gofflot S, Sinnaeve G, Dubois B, Bertin P, Mingeo D (2018) Reactivity of gluten proteins from spelt and bread wheat accessions towards A1 and G12 antibodies in the framework of celiac disease. Food Chem. https://doi.org/10.1016/j.foodchem. 2018.06.094

15. Hlisnikovský L, Hejcman M, Kunzová E, Menšík L (2019) The effect of soil-climate conditions on yielding parameters, chemical composition and baking quality of ancient wheat species Triticum monococcum L., Triticum dicoccum Schrank and Triticum spelt L. in comparison with modern Triticum aestivum L. Arch Agron Soil Sci. https://doi.org/10.1080/03650340.2018.1491033

16. Garvin DF, Welch RM, Finley JW (2006) Historical shifts in the seed mineral micronutrient concentration of US hard red winter wheat germplasm. J Sci Food Agric. https://doi.org/10.1002/jsfa. 2601

17. Fan MS, Zhao FJ, Fairweather-Tait SJ, Poulton PR, Dunham SJ, McGrath SP (2008) Evidence of decreasing mineral density in wheat grain over the last 160 years. J Trace Elem. https://doi.org/ 10.1016/j.jtemb.2008.07.002

18. Murphy KM, Reeves PG, Jones SS (2008) Relationship between yield and mineral nutrient concentrations in historical and modern spring wheat cultivars. Euphytica. https://doi.org/10.1007/ s10681-008-9681-x

19. Cakmak I, Pfeiffer WH, McClafferty B (2010) Biofortification of durum wheat with zinc and iron. Cereal Chem. https://doi.org/10. 5601/jelem.2016.21.4.1336

20. Hussain S, Sajjad A, Hussain MI, Saleem M (2001) Growth and yield response of three wheat varieties to different seeding densities. Int J Agri Biol 2:1560-8530

21. PSC (2011) Polish soil classification. Soil Sci Ann 3:1-193

22. IUSS Working Group WRB (2015) World Reference Base for soil resources 2014. International soil classification system for naming soils and creating legends for soil maps. Update 2015. World Soil Resources Report 106. FAO, Rome, p 188

23. ISO 6498:2012 Animal feeding stuffs-Guidelines for sample preparation

24. ISO 712:2009 Cereals and cereal products-Determination of moisture content-Reference method

25. AOAC Official Methods of Analysis (2019) American Assoc. of Official Analytical Chemists (21th edn). Gaithersburg

26. ISO 6869:2000 Animal feeding stuffs-Determination of the contents of calcium, copper, iron, magnesium, manganese, potassium, sodium and zinc-Method using atomic absorption spectrometry

27. ISO 6491:2000P Animal feeding stuffs-Determination of phosphorus content-Spectrometric method 
28. AACC American Assoc. of Cereal Chemists (2000) Approved methods of the American Association of Cereal Chemists (10th edn). American Assoc. of Cereal Chemists, St. Paul

29. Longin CFH, Ziegler J, Schweiggert R, Koehler P, Carle R, Würschum T (2016) Comparative study of hulled (Einkorn, Emmer, and Spelt) and naked wheats (Durum and Bread Wheat): agronomic performance and quality traits. Crop Sci. https://doi.org/ 10.2135/cropsci2015.04.0242

30. Lacko-Bartošova M, Otepka P (2001) Evaluation of chosen yield components of spelt wheat cultivars. JCEA 2:279-284

31. Rachoń L, Bobryk-Mamczarz A, Kiełtyka-Dadasiewicz A (2020) Hulled wheat productivity and quality in modern agriculture against conventional wheat species. Agriculture. https://doi.org/ 10.3390/agriculture 10070275

32. Harasim E, Wesołowski M (2013) Yield and some quality traits of winter wheat (Triticum aestivum L.) grain as influenced by the application of different rates of nitrogen. Acta Agrobot. https:// doi.org/10.5586/aa.2013.039

33. Geisslitz S, Scherf KA (2020) Rediscovering ancient wheats. CFW. https://doi.org/10.1094/CFW-65-2-0013

34. Escarnot E, Jacquemin JM, Agneessens R, Paquot M (2012) Comparative study of the content and profiles of macronutrients in spelt and wheat, a review. Biotechnol Agron Soc Environ 2:243-256

35. Rachoń L, Szumiło G, Woźniak A, Krochmal-Marczak B, Szafrańska A (2018) Nutritive value and mineral composition of husked and naked spring wheat species in relation to cultivation technology. Fragm Agron 4:93-102

36. Rachoń L, Szumiło G, Brodowska M, Woźniak A (2015) Nutritional value and mineral composition of grain of selected wheat species depending on the intensity of a production technology. $\mathrm{J}$ Elem. https://doi.org/10.5601/jelem.2014.19.4.640

37. Biel W, Stankowski S, Jaroszewska A, Pużyński S, Bośko P (2016) The influence of selected agronomic factors on the chemical composition of spelt wheat (Triticum aestivum ssp. spelta L.) grain. J Integr Agric. https://doi.org/10.1016/S2095-3119(15) 61211-4

38. Laidig F, Piepho HP, Rentel D, Drobek T, Meyer U, Huesken A (2017) Breeding progress, environmental variation and correlation of winter wheat yield and quality traits in German official variety trials and on-farm during 1983-2014. Theor Appl Genet. https:// doi.org/10.1007/s00122-016-2810-3

39. Hussain A, Larsson H, Kuktaite R, Johansson E (2010) Mineral composition of organically grown wheat genotypes: contribution to daily minerals intake. Int J Environ Res Public Health. https:// doi.org/10.3390/ijerph7093442

40. Michel S, Kummer C, Gallee M, Hellinger J, Ametz Ch, Akgöl B, Epure D, Löschenberger F, Buerstmay H (2018) Improving the baking quality of bread wheat by genomic selection in early generations. Theor Appl Genet. https://doi.org/10.1007/ s00122-017-2998-x

41. Hellemans T, Landschoot S, Dewitte K, Van Bockstaele F, Vermeir P, Eeckhout M, Haesaert G (2018) Impact of crop husbandry practices and environmental conditions on wheat composition and quality: a review. J Agric Food Chem. https://doi.org/10.1021/acs. jafc. $7 \mathrm{~b} 05450$

42. Krochmal-Marczak B, Sawicka B (2016) The nutritional value of spelled (Triticum spelta $\mathrm{L}$.) cultivated on Podkarpacie region. Herbalism. https://doi.org/10.12775/HERB.2016.012

43. Shewry PR, Pellny TK, Lovegrove A (2016) Is modern wheat bad for health? Nat Plants 2:16097

44. Arzani A, Ashraf M (2017) Cultivated ancient wheats (Triticum spp.): a potential source of health-beneficial food products. Compr Rev Food Sci Food Saf. https://doi.org/10.1111/1541-4337.12262
45. Hidalgo A, Brandolini A (2014) Nutritional properties of einkorn wheat (Triticum monococcum L.). J Sci Food Agric. https://doi. org/10.1002/jsfa.6382

46. Soetan KO, Olaiya CO, Oyewole OE (2010) The importance of mineral elements for humans, domestic animals and plants: a review. Afr J Food Sci 4:200-222

47. Morgounov AI, Belan I, Zelenskiy Y, Roseeva L, Tomoskozi S, Bekes F, Abugalieva A, Cakmak I, Vargas M, Crossa J (2013) Historical changes in grain yield and quality of spring wheat varieties cultivated in Siberia from 1900 to 2010. Can J Plant Sci. https:// doi.org/10.4141/cjps2012-091

48. Genc Y, MacDonald GK (2008) Domesticated emmer wheat ( $T$. turgidum L. subsp. dicoccon (Schrank) Thell.) as a source for improvement of zinc efficiency in durum wheat. Plant Soil. https:// doi.org/10.1007/s11104-008-9630-4

49. Zhao FJ, Su YH, Dunham SJ, Rakszegi M, Bedo Z, McGrath SP, Shewry PR (2009) Variation in mineral micronutrient concentrations in grain of wheat lines of diverse origin. J Cereal Sci. https:// doi.org/10.1016/j.jcs.2008.11.007

50. White PJ, Broadley MR (2009) Biofortification of crops with seven mineral elements often lacking in human diets-iron, zinc, copper, calcium, magnesium, selenium and iodine. New Phytol. https://doi.org/10.1111/j.1469-8137.2008.02738.x

51. Rosanoff A, Dai Q, Shapses SA (2016) Essential nutrient interactions: does low or suboptimal magnesium status interact with vitamin $d$ and/or calcium status? Adv Nutr 1:25-43

52. Ostrowska A, Porębska G (2017) The content of calcium and magnesium and the $\mathrm{Ca}: \mathrm{Mg}$ ratio in cultivated plants in the context of human and animal demand for nutrients. J Elem 3:995-1004

53. Wojtkowiak K, Stępień A, Warechowska M, Konopka I, Klasa A (2014) Effect of fertilisation technique on some indices of nutritional value of spring triticale grain. J Elem. https://doi.org/10. 5601/jelem.2014.19.1.590

54. Majkowska-Gadomska J (2006) Effect of sorbents on concentrations of some trace elements in butter-head lettuce (Lactuca sativa L. var capitata L.). Pol J Environ Stud. https://doi.org/10.5601/ jelem.2013.18.2.06

55. Vorland CJ, Stremke ER, Moorthi RN, Gallant KMH (2017) Effects of excessive dietary phosphorus intake on bone health. Curr Osteoporos Rep. https://doi.org/10.1007/s11914-017-0398-4

56. Pontieri P, Troisi J, Di Fiore R, Di Maro A, Bean SR, Tuinstra MR, Roemer E, Boffa A, Del Giudice A, Pizzolante G, Alifano P, Del Giudice L (2014) Mineral contents in grains of seven foodgrade sorghum hybrids grown in a Mediterranean environment. Aust J Crop Sci 8:1550-1559

57. Vashishth A, Ram S, Beniwal V (2017) Cereal phytases and their importance in improvement of micronutrients bioavailability. Biotech. https://doi.org/10.1007/s13205-017-0698-5

58. Schlemmer U, Frølich W, Prieto RM, Grases F (2009) Phytate in foods and significance for humans: food sources, intake, processing, bioavailability, protective role and analysis. Mol Nutr Food Res. https://doi.org/10.1002/mnfr.200900099

59. Afify AEMM, El-Beltagi HS, El-Salam SMA, Omran AA (2011) Bioavailability of iron, zinc, phytate and phytase activity during soaking and germination of white sorghum varieties. PLoS ONE. https://doi.org/10.1371/journal.pone.0025512

60. WHO (2002) World Health Organization Report 2002: Reducing risks, promoting healthy life. World Health Organization, Geneva

61. Gibson RS, Hotz C, Temple L, Yeudall F, Mtitimuni B, Ferguson E (2000) Dietary strategies to combat deficiencies of iron, zinc, and vitamin A in developing countries: development, implementation, monitoring, and evaluation. Food Nutr Bull. https://doi.org/ $10.1177 / 156482650002100218$

62. Nair KM, Brahmam GN, Radhika MS, Dripta RC, Ravinder P, Balakrishna N, Chen Z, Hawthorne KM, Abrams SA (2013) Inclusion of guava enhances non-heme iron bioavailability but not 
fractional zinc absorption from a rice-based meal in adolescents. J Nutr. https://doi.org/10.3945/jn.112.171702

63. Kordas K, Stoltzfus RJ (2004) New evidence of iron and zinc interplay at the enterocyte and neural tissues. J Nutri 6:1295-1298

64. Rietra RPJJ, Heinen M, Dimkpa CO, Bindraban PS (2017) Effects of nutrient antagonism and synergism on yield and fertilizer use efficiency. Commun Soil Sci Plant Anal. https://doi.org/10.1080/ 00103624.2017.1407429

65. Maret W, Sandstead HH (2006) Zinc requirements and the risks and benefits of zinc supplementation. J Trace Elem Med Biol. https://doi.org/10.1016/j.jtemb.2006.01.006

66. Badigannavar A, Girish G, Ramachandran V, Ganapathi TR (2016) Genotypic variation for seed protein and mineral content among post-rainy season-grown sorghum genotypes. Crop J. https://doi.org/10.1016/j.cj.2015.07.002

67. Chatzav M, Peleg Z, Ozturk L, Yazici A, Fahima T, Cakmak I, Saranga Y (2010) Genetic diversity for grain nutrients in wild emmer wheat: potential for wheat improvement. Ann Bott. https:// doi.org/10.1093/aob/mcq024

68. Cousins RJ (2006) In: Bowman BAB, Russell RM (eds) Present knowledge in nutrition. ILSI Press, Washington, DC

69. Peleg Z, Cakmak I, Ozturk L, Yazici A, Jun Y, Budak H, Korol AB, Fahima T, Saranga Y (2009) Quantitative trait loci conferring grain mineral nutrient concentrations in durum wheat $\times$ wild emmer wheat RIL population. Theor Appl Genet. https://doi.org/ 10.1007/s00122-009-1044-z

70. Pandey A, Khan MK, Hakki EE, Thomas G, Hamurcu M, Gezgin S, Akkaya MS (2016) Assessment of genetic variability for grain nutrients from diverse regions: potential for wheat improvement. Springerplus. https://doi.org/10.1186/s40064-016-3586-2

71. Munteanu MG, Voicu G, Ungureanu N, Zăbavă BS, Ionescu M, Constantin GA, Istrate I (2019) 46. Symposium "Actual Tasks on Agricultural Engineering”, Opatija, Croatia, 2018
72. Aydoğan S, Şahin M, Akçacik AG, Hamzaoğlu S, Taner S (2015) Relationships between farinograph parameters and bread volume, physicochemical traits in bread wheat flours. Crop Sci 3:14-18

73. Okuda R, Tabara A, Okusu H, Seguchi M (2016) Measurement of water absorption in wheat flour by mixograph test. J Food Sci Technol. https://doi.org/10.3136/fstr.22.841

74. Makawi AB, Mahmood MI, Hassan HAR, Ahmed IAM (2013) Grains quality characteristics of local wheat (Triticum aestivum) Cultivars Grown at Khartoum State, Sudan. Int J Life Sci. https:// doi.org/10.3126/ijls.v7i1.8061

75. Rao BN, Pozniak CJ, Hucl PJ, Briggs C (2010) Baking quality of emmer-derived durum wheat breeding lines. J Cereal Sci. https:// doi.org/10.1016/j.jcs.2010.01.004

76. Lacko-Bartošová $\mathrm{M}$, Konvalina $\mathrm{P}$, Lacko-Bartošová L, Štěrba $\mathrm{Z}$ (2019) Quality evaluation of emmer wheat genotypes based on rheological and Mixolab parameters. Czech J Food Sci. https:// doi.org/10.17221/101/2018-CJFS

77. Tomić JM, Torbica AM, Popović LM, Rakita SM, Živančev DR (2015) Bread making potential and proteolytic activity of wheat varieties from two production years with different climate conditions. Food Feed Res. https://doi.org/10.5937/FFR1502083T

78. Torbica A, Belović M, Popović L (2002) Comparative study of nutritional and technological quality aspects of minor cereals. $\mathbf{J}$ Food Sci Technol. https://doi.org/10.1007/s13197-020-04544-w

79. Marconi E, Carcea M, Schiavone M, Cubadda R (2002) Spelt (Triticum spelta L.) pasta quality: Combined effect of flour properties and drying conditions. Cereal Chem. https://doi.org/10.1094/ CCHEM.2002.79.5.634

Publisher's Note Springer Nature remains neutral with regard to jurisdictional claims in published maps and institutional affiliations. 